\title{
IS IT ALL GOING TO WASTE? ILLEGAL TRANSPORTS OF E-WASTE IN A EUROPEAN TRADE HUB
}

\section{Lieselot Bisschop ${ }^{1}$}

Bisschop, L. (2012). Is it all going to waste? Illegal transports of e-waste in a European trade hub. Crime, Law and Social Change, Online First: 30 July 2012 (DOI 10.1007/s10611-012-9383-0).

ABSTRACT: This article responds to the call for more empirical knowledge about transnational environmental crime. It does so by analysing the case of illegal transports of electronic waste (e-waste) in a European trade hub. Given the complexity and global nature of transnational environmental crime, it is difficult to determine which actors are involved. In this regard, a local research setting allows the actors involved in illegal transports of e-waste to be identified. This research tries to determine whether these actors and their roles can be considered legal or illegal and illustrates the legal-illegal interfaces in e-waste flows. Moreover, this case study analyses the push, pull and facilitating factors and therefore looks at what motivations and opportunities shape the flows of e-waste in locations of origin, transit and destination. The results show that the social organisation and emergence of transnational environmental crime is on a thin line between legal and illegal which needs to be contextualised within the global reality of the locations of origin, transit and destination.

KEY WORDS: transnational environmental crime; social organisation of crime; push, pull and facilitating factors; illegal transports; e-waste; case study

\section{INTRODUCTION}

In response to a higher awareness about hazardous waste and more stringent regulations in the industrialised countries [1], waste is transported to less affluent regions of the world [2,3]. One of those waste flows ${ }^{2}$ is e-waste ${ }^{3}$, often transported with the label of 'second hand goods'. Much of the electronic and electric equipment (EEE) that is transported to developing countries never makes it to the second hand market and is dismantled to extract the raw materials. All too often this 'recycling' happens in precarious circumstances, where the remains are illegally dumped or burned, releasing their toxic components ${ }^{4}$ into the atmosphere and into the lungs of those nearby [4]. The hazardous components such as heavy metals, oil, cooling liquids and gasses disseminate into soil, air and water, harm eco-systems and indirectly affect the quality of crops and drinking water [5-9]. The harm lies in the environmental degradation and damage to

\footnotetext{
${ }^{1}$ Researcher at the Faculty of Business and Public Administration of University College Ghent and PhD Candidate at the Department of Criminal Law and Criminology of Ghent University (Ghent, Belgium) lieselot.bisschop@ugent.be

2 Flows refer to departure locations, followed routes and final destinations of goods.

${ }^{3}$ E-waste is waste from electronic and electric equipment, such as television sets, refrigerators, computers, mp3 players, etc.

${ }^{4}$ Many electronic and electrical devices contain lead, cadmium, brominated flame retardants, beryllium and mercury
} 
health as well as the precarious working circumstances in recycling facilities in Africa and Asia [10-12]. In addition, these illegal transports of e-waste can be harmful economically and politically through unfair price settings and lower material recovery rates ${ }^{5}$, and undermine (inter)national environmental policy making and law enforcement [13]. This illustrates that the inadequate treatment of e-waste is an immediate and future threat for human health and ecology, for economy and politics. This is why illegal transports of (e-)waste have been identified as a major form of environmental crime by the international community. The discovery of and media attention for dump sites of toxic waste in developing countries during the 1980s and 1990s led to the adoption of international and European legislative frameworks that regulate (e-)waste transports ${ }^{6}$.

Criminology has however been rather silent about environmental crime (e.g. illegal transports of ewaste) for many years [14-16]. Eco-global, green and environmental issues are increasingly part of the criminological agenda [3,17-21], but despite this increased interest in transnational environmental crime, analyses often lack methodological strength. Because empirical studies provide input for theoretical progress, this article responds to the call for more empirical knowledge about transnational environmental crime $[17,22,23]$ by focusing on the characteristics of one particular phenomenon: the illegal transports of electronic waste (e-waste). First, this study identifies the legal and illegal actors involved in this case and thus provides insights into the social organisation of it. Second, the emergence of illegal transports of e-waste is studied by analysing the push, pull and facilitating factors within this European research setting. This article builds upon earlier publications about this topic that addressed issues of white-collar crime associated with global e-waste trade [3]. This analysis focuses in particular on the European context, because this is a region that is considered a forerunner in environmental policy and legislation [24].

The structure of this article is as follows. First, the theoretical background about legal-illegal interfaces (social organisation) and push, pull and facilitating factors (emergence) is discussed. Second, the method and research setting of this case study research is explained. A third section discusses the scope of illegal transports of e-waste in Europe and the Belgian research setting (the port of Antwerp) together with an overview of the challenges this brings for data gathering. There follows an analysis of the social organisation and emergence of illegal transports of e-waste. Findings about the legal and illegal actors

\footnotetext{
5 "Environmentally sound and efficient facilities recycle 17 to 18 metals in a mobile phone, extracting about $95 \%$ of the gold, whereas in developing countries about 3 or 4 metals are extracted, with a recovery rate of $25 \%$ for gold." (author's interview with corporate sector respondent C15).

${ }^{6}$ Basel Convention on the control of transboundary movements of hazardous wastes and their disposal (adopted on 22 March 1989, entered into force on 5 May 1992); Basel Convention Ban Amendment, 22 September 1995; Montreal Protocol on ozone-depleting substances Montreal, 16 September 1987 (entered into force 1 January 1989); and OECD Decision on control of cross-border movements of waste destined for recovery operations (Decision of the Council C(2001)107/Final (as Amended By C(2004)20)). European Waste Shipment Regulation (Regulation (EC) No $1013 / 2006$ of the European Parliament and of the Council of 14 June 2006 on shipments of waste (OJ L 190, 12.7.2007, 1-98); Directive 2002/96/EC of the European Parliament and of the Council of 27 January 2003 on waste electrical and electronic equipment (WEEE) (OJ L 37, 13.02.2003, pp.24-38); Directive 2006/12/EC of the European Parliament and of the Council of 5 April 2006 on waste; Directive 2005/32/EC of the European Parliament and of the Council of 6 July 2005 establishing a framework for the setting of eco-design requirements for energy-using products and amending Council Directive 92/42/EEC and Directives 96/57/EC and 2000/55/EC of the European Parliament and of the Council. Bamako Convention on the ban of the import into Africa and the control of transboundary movement and management of hazardous wastes within Africa (Signed 30 January 1991, entered into force on 22 April 1998).
} 
involved and their interfaces are integrated with findings on their motivations and opportunities, which equal the push, pull and facilitating factors in these flows. In the discussion, this article reconsiders the legal-illegal interface in the social organisation and emergence of e-waste flows and looks at implications for policy and theory about transnational environmental crime. In the concluding section the article's main findings are summarized.

\section{THEORETICAL BACKGROUND}

This article examines both the social organisation and emergence of illegal transports of e-waste. Before discussing the results of this study, the theoretical background for both of these topics is discussed. Transnational environmental crime is complex and diversified. Given the complexity and global nature of these flows, it is in fact difficult to determine which actors are involved. This is not necessarily limited to corporate actors, neither does it mean that it necessarily involves organised crime [25-27]. A diversity of actors can play a role and therefore research should consider a wide range of possible actors, beyond whitecollar crime, organised crime or state crime conceptualizations $[26,28,29]$. Both small- and large-scale actors, both the powerful and the less affluent and both legal and illegal actors might play a role. It may prove difficult to draw a line between legal and illegal actors and their practices, but it is necessary to gain a more accurate view of the network of actors and their interrelations. This can further theoretical developments as well as provide input for policy making. This article therefore tries to determine whether the actors involved in transports of e-waste and the roles they play can be considered legal or illegal. This article analyses whether both legal and criminal actors are involved and whether there is an interface between the two $[26,28,30]$. The theoretical background for these legal-illegal interfaces in transnational crime relates back to the framework developed by Passas [26,31] which was further refined by Tijhuis by applying it to the illicit antiquities and art trade [29]. The two broad categories are antithetical and symbiotic interfaces. In general, antithetical interfaces are those where legal and illegal actors oppose each other, whereas symbiotic interfaces are those where they cooperate. Four antithetical and six - or eight in Passas' typology ${ }^{7}$ - symbiotic relations can be distinguished $[26,29]$. In what follows, each is explained briefly and the type is mentioned in brackets. The four antithetical interfaces are: illegal actors compete with legal actors on the same market (antagonistic); illegal actors harm legal actors (injurious); illegal actors extort legal actors while keeping them viable (parasitical); or illegal actors aim to destroy the legal business (predatory). There are six types of symbiotic interfaces: legal actors hire an illegal actor to do the dirty work for them (outsourcing); both do business independently in which they benefit from each other but one is unaware of the illegality (synergy); legal and illegal actors have a long lasting strong link and are both aware of the illegality (collaboration); both experience benefits and are aware of the illegality (reciprocity); both experience benefits but within an uneven power relation (co-optation); and legal actors financially support illegal ones (funding). Passas [31] also referred to legal actors who are committing organised crimes and legal actors who pursue legal activities,

7 Passas refers to eight symbiotic interfaces. Tijhuis omitted two of those from his typology. 
whereas Tijhuis [29] believed those categories not to be referring to illegal-legal interfaces and therefore left those out of his typology. These interfaces have not been studied often and therefore this article analyses the legal-illegal interfaces for one particular type of transnational crime: illegal transports of e-waste. This will allow us to explore the fine line between legal and illegal. It this way, this study aims to gain insights into the social organisation of illegal transports of e-waste.

The social organisation of illegal transports of e-waste needs to be understood against a broader political, social, economic and cultural background. This can provide insights into the underlying causes of transnational environmental crime [26,32]. Analysing factors that contribute to the emergence of illegal transports of e-waste is the second objective of this article. In essence, this aetiological question has occupied criminology since its emergence, but the aetiology of both transnational and environmental crimes was long disregarded [28,33]. Different theories in criminology ${ }^{8}$ might help understand the emergence of illegal transports of e-waste, but the integration of these theories results in three core elements: criminalisation, motives and opportunities [34]. This article does not focus on the criminalisation of illegal transports of ewaste, but does analyse the motives and opportunities. In doing this, it pays attention to individual, organisational and societal levels of analysis because each might contribute to the emergence of illegal ewaste flows [35-38]. Characteristics of the sector or the product might be motives or opportunities for (organised) crime $[39,40]$. The transport sector can for example be a victim of crime, but might well be a facilitator of crime [41,42]. Furthermore the unlevel playing field in today's globalised world can play a role, because these asymmetries foster the demand for illegal goods or services, are an incentive to participate in illegal markets and hamper the ability of authorities to control [43, p.402]. Applying this to environmental matters, asymmetries in environmental regulation or ambiguities in enforcement can contribute to jurisdiction (s)hopping, in which one goes in search of the most favourable (illegal) agreement for the trade of hazardous waste or for the space between laws. Heightened environmental awareness in industrialised countries (cultural asymmetry) led to the strengthening of environmental legislation and to the criminalisation of certain behaviour (legal asymmetry), caused prices to rise (economic asymmetry) and gave extra incentives for illegal trading of waste to countries with lower environmental awareness, lower environmental regulatory standards and lower prices [44]. For that reason, it is important to place transnational environmental crime within the broader context of today's globalised society which might facilitate crime [45]. Given the inherently transnational character of these flows, factors in countries of origin, transit and destination should be considered $[20,46]$. The motivations and opportunities for illegal e-waste transports can in fact be located in exporting and importing countries, in supply and demand and are impossible to explain while disregarding the economic, political, cultural and social context [20]. This study

8 Strain, social control, differential association, labelling, neutralisation and rational choice theory can each provide insights on the aetiology of crime. 
therefore identifies push, pull and facilitating factors that will help understand how and why illegal transports of e-waste occur'.

Push factors are those forces that drive illegal transports of e-waste away from their origin (supply). Pull factors are forces that draw illegal transports of e-waste to their destination (demand). Facilitating factors are contextual elements that make illegal transports of e-waste possible. Together, these factors provide the motives and opportunities for actors involved in illegal transports of e-waste. As evident from the different elements discussed above, the aetiology cannot be reduced to one explanatory factor, because "each time we subscribe to one cause of crime, we may realize that the opposite cause also possesses reasonable validity" [48, p.6 $]^{10}$. Earlier publications [3] referred to profit or lure as the major aetiological factors, but this article illustrates how these are key elements, yet they require more contextualisation. Before discussing the social organisation and emergence of illegal transports of e-waste, the method of this study is discussed.

\section{METHOD}

Research on transnational environmental crime requires looking beyond the classical - and inherently limited - data of the enforcement agencies and thus requires a search for alternative perspectives. Data was collected on as many observable implications of the studied phenomenon as possible to improve the quality of the data [49]. By corroborating different perspectives and opinions about the cases the arguments were exposed to validation or falsification at different times. This refers to the different segments of society the respondents represent (government, corporate, civil society). The triangulation of different methods, data as well as theory, also contributes to this [50]. This study is based on a document analysis of various primary and secondary sources, on interviews with key informants and on field visits. The document analysis is based on governmental sources (reports and statistics of inspectorates, police and customs, trade statistics), research reports (UNEP ${ }^{11}$, IMPEL(TFS) ${ }^{12}$, INECE ${ }^{13}$, Interpol, World Bank, independent consultants and academics), corporate documents (press releases, websites, year reports) and documents by civil society actors (environmental organisations, nongovernmental organisations (NGOs), the media). In addition to the document analysis, a total of 50 semi-structured interviews were conducted with 29 government, 19 private sector and 14 civil society actors. ${ }^{14}$ The governmental actors in this research are national and international government agencies, such as customs, environmental inspectorates, police organisations, prosecution service and administrations. The corporate representatives who were interviewed are producers of computer

\footnotetext{
${ }_{9}$ Push, pull and facilitating factors refer back to economic dynamics of supply and demand. These have been applied to transnational crimes in previous articles $[46,47]$.

10 Ruggiero [48] refers to this as the 'causality of contraries' (p.6).

11 United Nations Environment Programme.

12 European Network for the Implementation and Enforcement of Environmental Law. TFS is a subgroup of IMPEL that focuses on the inspection and enforcement of Transfrontier Shipments of Waste.

13 International Network for Environmental Compliance and Enforcement.

14 Interviews ranged from 45 minutes to 2 hours in length. The number of interviews and number of respondents differs because some actors chose to address the researcher in pairs and four individuals were interviewed twice. In addition, there was one group interview with thirteen government respondents, four of whom were also interviewed separately.
} 
hardware, e-waste collectors, refurbishers and recyclers, and transport corporations. ${ }^{15}$ The civil society respondents in this research are environmental NGOs, union representatives and research journalists. These respondents were located within the Belgian research setting as well as in other EU countries, as locations of origin, and in Ghana as one of the countries of destination. All but one respondent agreed for the interview to be digitally recorded. A checklist was used to guide both the document analysis and the interviews. The analysis was based on both the researcher's notes and transcriptions of the recordings. Besides the document analysis and the interviews, this research included field visits, which were necessary to gain contextualised information about the flows [50]. These field visits did not involve extensive participatory observation, but were limited to crucial sites and actors in the illegal e-waste flows. I joined customs and the federal environmental inspectorate in the port of Antwerp. This focused on the export and transit of e-waste, because these transport modalities of e-waste are relevant to the research setting of the port of Antwerp. ${ }^{16}$ Besides field visits in the port of Antwerp, I visited one country of destination (Ghana) that is often frequented by illegal transports of e-waste that export from or transit in Belgium. I also visited the port of Tema, the informal recycling and refurbishing firms and e-goods markets in Tema and Accra, and the Agbogbloshie dumpsite. I made notes during and/or after these field visits which were integrated in the data analysis with the interviews and document analysis [52]. Data gathered in both desk research and interviews was coded and analysed by means of qualitative data analysis software ${ }^{17}$, which made it possible to triangulate findings from different types of sources [53-55].

This case study focuses on a European research setting, because Europe can be considered a forerunner in environmental policy making [24]. Specifically, the research setting is the port of Antwerp in Belgium. This setting was chosen because Antwerp is an economically important port and has been referred to in the past as a waste hub ${ }^{18}$. Antwerp handles about 8.5 million TEU ${ }^{19}$ annually and is amongst the top three ports in Europe, with Rotterdam and Hamburg ${ }^{20}$. For the transit and export of second-hand vehicles, which play an important role in e-waste transports, Antwerp is the most important port in Europe. Given its inland location, the port has multiple connections to Europe's hinterland and it is therefore a typical transit hub21. By basing this research within this local setting, I aimed to avoid too relativistic findings about transnational environmental flows [60]. At the same time, the different transferences influencing this locality

\footnotetext{
15 These respondents were guaranteed anonymity and therefore I refer to government ( $\mathrm{G}$ and number), corporate ( $\mathrm{C}$ and number) and civil society respondents ( $\mathrm{S}$ and number) for citations. This case study is part of a broader PhD research study on transnational environmental crime, which also included another case study(tropical timber [51]). There is one list of respondents for both cases and respondents were numbered consecutively.

16 Import flows are predominantly destined for the major recycling facilities in the EU and therefore not relevant to the transnational environmental crime flows subject of this research.

17 NVivo qualitative data analysis software; QSR International Pty Ltd. Version 8, 2008

18 See, for example, Belgian news reports [56-59]

19 TEU refers to "twenty-foot equivalent unit", a container of 20 feet long, 8 feet high and 8 feet wide. This is used as a standard measuring reference for container traffic.

20 Antwerp was the second largest European port after Rotterdam until February 2012, when it was overtaken in terms of container volume by Hamburg. It remains the first for second-hand vehicles.

21 of all the freight, $37 \%$ is loaded back onto sea-going vessels and 35\% goes to neighbouring countries by inland shipping and rail. Only $12 \%$ is destined for companies located in the port and $16 \%$ is for Belgian distribution.
} 
were examined by placing e-waste within the broader frame of departure locations, routes followed and final destinations - the flows of e-waste [61].

\section{THE SCALE OF ILLEGAL TRANSPORTS OF E-WASTE: BEST GUESSTIMATES FOR EUROPE AND BELGIUM}

Measuring environmental crime is complex [62] and it is difficult to assess [63]. Illegal transports of e-waste are no exception. This is a phenomenon about which there is little official data, despite the waste issue being on the international ${ }^{22}$ as well as national policy agenda ${ }^{23}$. Illegal transports of e-waste in fact present multiple challenges for data gathering and analysis. The Basel Secretariat keeps track of the hazardous waste transports of their parties. This information is however not always readily available: not all parties to the convention report meticulously and some do not report at all24. The European Union has a yearly reporting system for shipments of hazardous and problematic waste, but does not have a common database for waste transports in breach of regulation.

The reported data on e-waste of both the Basel Secretariat and the EU is generally of poor quality [66]. Possible reasons for this are: (1) the waste codes are not harmonized and e-waste can be covered by different codes of the system; (2) the codes are interpreted differently across the reporting parties, making country comparisons impossible 25 ; (3) e-waste transports are often transported under the heading of "recyclable electronics" and not reflected in WEEE statistics ${ }^{26}$; (4) within one country different organisations (inspectorates, customs, administration, police) report to the European Commission leading to possible double reporting27; (5) European targets are based on kilograms of waste controlled, which distorts the figures and the effectiveness of the controls in avoiding environmental harm ${ }^{28}$; (6) EU member states' official take-back systems only account for a portion of the discarded EEE ${ }^{29}$. The amount of UEEE/WEEE from corporate consumers is unknown as is the size of the second-hand market [68]. Moreover, the data gathered by the EU and the Basel Secretariat can tell us about reported movements of hazardous waste and not necessarily about illegal transports. Existing reports of illegal transports are a result of the controls rather than a reflection of the actual illegal transports occurring. As an example, controls by all Belgian inspectorates

22 E.g. Basel Convention, Interpol, IMPEL, EU.

23 E.g. Belgian National Security Plan 2008-2011 (p.7) and 2012-2015 (p.15).

24 It is sometimes possible however to estimate the hazardous waste transports of non-reporting countries based on import and export data of others [64,65].

25 The reporting requirement in WEEE regulation will be more detailed in the future.

26 As an example, only 20,000 tonnes of WEEE is mentioned in the EU 2001-2003 statistics. Given that the estimated generation in the EU is 7 million tonnes this seems a rather small figure.

27 This is likely to apply to Belgium, since different federal and regional authorities have their own responsibilities in waste transport matters. Waste transit is a federal responsibility; waste export and import is a regional responsibility; notifications data is collected by the Flemish public waste authority (Openbare Vlaamse Afvalstoffenmaatschappij (OVAM)).

28 "A fridge weighs a lot more than an iPod, but the latter are the most interesting because they contain the precious metals" (S14).

29 "The collection target of $4 \mathrm{~kg}$ per person per year does not properly reflect the amount of WEEE arising in individual Member States" [67]. With a 45\% share of the e-waste for Flanders, the official take-back system Recupel is amongst the best of the EU class, according to a Belgian government respondent. 
are at a maximum since 2007-2008 and therefore the reports might be more a reflection of the limited personnel resources than of the actual flows.

With the above challenges to the data in mind, it should be understandable that the scope of the illegal transports of e-waste globally, on a European level or within the research setting of the port of Antwerp, can only be represented by "best guesstimates". The data on illegal transports of e-waste provided in this article are therefore given for illustration purposes and should not be regarded as incontestable figures. Many of these statistics are intangible, because there is no frame of reference. Gathering global data about e-waste transports is therefore necessarily a matter of patchwork. It does however provide a general idea about the scope and the directions of the transports. In what follows, a picture is painted of the scope of the illegal flows of e-waste within the EU. This is contextualised with global information about (legal) flows and generation of e-waste. Next, this article discusses import, export and transit in the Belgian e-waste market.

\section{The EU and e-waste}

Shipments of waste within and out of the EU-15 increased from 2.7 million tonnes in 1997 to 8.3 million tonnes in 2003 [66, p.39]. These transports equal a 15\% share of all EU transports [69]. Most waste transports stay within the EU or take place between OECD countries. Of total waste transports 83\% is meant for recovery and $17 \%$ for disposal. However, countries provide very limited information about the amounts or the final destination of goods, making it difficult to assess trends. Based on the Basel data, Wielenga [65] concludes that " $[\mathrm{t}]$ here is no evidence that significant amounts of hazardous wastes are being transferred from richer countries to poorer countries". IMPEL-TFS projects [69] however found 51\% of shipments to non-OECD countries to be illegal. ${ }^{30,31}$ The illegal transports of waste reported to the EC increased from 2001 to 2005: between 6,000 and 47,000 tonnes of illegal shipments are reported yearly. This equals just $0.2 \%$ of the notified waste and therefore likely represents only a fraction of the actual transports [7]. As mentioned earlier, this could well be due to more enforcement efforts or more meticulous reporting by particular Member States and does not necessarily imply an increase in shipments.

The most important member states for shipments of e-waste - import, export and transit - are Germany, the Netherlands, Belgium and the United Kingdom and these countries also register most illegal transports. A part of these flows might however simply be a result of economic and geographic realities, because these countries have economically significant ports and function as a transit for inland Europe. ${ }^{32}$

30 This percentage is based on limited action periods by IMPEL-TFS partners across Europe. Belgium, with the ports of Antwerp, Zeebrugge, Ostend and Ghent, was one of the participating member states.

31 Between March and May 2009, 64 countries in Europe, Asia/Pacific and Africa participated in the World Customs Organisation initiative 'Demeter'. This targeted illegal transboundary movements of hazardous waste from Europe to Asia-Pacific and Africa. It resulted in 57 seizures (totally 30,000 tonnes and 1,500 pieces of illegal hazardous waste) of which the majority occurred in Belgium, the Netherlands and Italy [70].

32 Geographically, Switzerland, a land without seaports, relies on exports to neighbouring EU countries. It is known to ship waste directly to Belgium, Bulgaria, France, Germany, Poland, Italy, Romania, Serbia, Spain and the Netherlands, but indirectly transports to Africa, Gabon, Nigeria, Brazil and Togo. Germany has an own seaport (Hamburg), but given the 
Rotterdam and Antwerp have been labelled as hubs for (illegal) waste shipments [72,73], but given that these ports serve shipping routes to Africa and China, the high number of waste transports to non-OECD countries could partially be a mere economic given. According to both corporate and governmental respondents, these ports are victim to their own law enforcement success: ports in Spain, Italy and France hardly ever exercise any control over illegal e-waste transports thereby reducing their likelihood of having high statistics [20].

Note that there is flexibility in the routes the illegal transports follow. As soon as more stringent controls are in place in one European port, the transports move to another port. The major shipping lines have storage facilities in different ports to allow these deviations. According to the respondents this happens between the ports of Rotterdam, Antwerp, Hamburg, Felixstowe, Le Havre and Bilbao.

Besides these trade and trade control data, figures about WEEE generation provide information on ewaste for the EU. This is estimated to grow 3 to $5 \%$ because of increased use of electrical and electronic equipment ${ }^{33}$, adding up to 10.5 million tonnes, or 15 to $20 \mathrm{~kg}$ of electronic and electric equipment brought onto the market per capita per annum [75]. About 7\% of this is registered as WEEE exports and up to 33\% is separately collected for environmentally sound treatment [76]. "A part of the other two thirds is potentially still going to landfills and to sub-standard treatment sites in or outside the European Union. Illegal trade of electrical and electronic waste to non-EU countries continues to be identified at EU borders" [67] ${ }^{34}$. Reports indicate that the flows of WEEE/UEEE go from Western Europe and the USA to West Africa and South East Asia [66,75]. ${ }^{35}$ Transports towards Africa are most likely to be e-waste or low quality second-hand products $[7]^{36}$. There are no details available about the final destination of the components or metal scrap, but in Ghana the motherboards of the dismantled computers were found to be sold as a whole for export to Nigeria or China, whereas other recovered metals are used in local industries or sold for export [78]. Data on e-waste transports are inevitably guesstimates, but provide the necessary contextualisation for discussing the Belgian research setting. This article now shifts its focus to flows of e-waste in Belgium and the port of Antwerp.

\section{Import, export and transit on the Belgian e-waste market}

First, a brief introduction about the role of the port of Antwerp in (e-)waste transports is provided. Thereafter, the import, export and transit of e-waste in Belgium are discussed in terms of both scope and geographical orientation. Antwerp is an economically significant trade and waste hub [5], but mainly as a port of transit: $80 \%$ of all waste is in transit, whereas only $20 \%$ of waste is imported into or exported out of Belgium. A lot of the waste in Antwerp is in transit from Germany, Austria, Switzerland, France and to a lesser

size of the country and the distance to Hamburg it is often economically more feasible to ship goods through the ports of Rotterdam and Antwerp from the nearby Länder (e.g. Northrein-Westfalen). These shipments are not necessarily problematic or illegal, but have proven to be worrisome in the past [71].

${ }^{33}$ Studies are trying to forecast future global generation of e-waste [74]

34 Similar figures are found in the US, where 25 to $35 \%$ of e-waste is recycled $[3,77]$. The EC has now set a $65 \%$ target for 2012-2013 [67].

35 Lagos in Nigeria is estimated to receive about 500 containers per month [6], of which 45\% originates in Europe [75], $45 \%$ the United States and 10\% Japan, Israel and others [10]. These estimates are based on asset tags on the equipment and on other identifiers.

36 They did so by analysing the amount of television sets exported from the EU and checking the value of the shipments. 
extent the Netherlands. The most frequent countries of destination in West Africa are Nigeria, Ghana, Cameroon, Togo and Senegal, partially due to Antwerp's trade connections with this region. As an illustration, Ghana, Benin, Ivory Coast, Liberia and Nigeria import about 250,000 tonnes per annum illegally [79]. Besides the West African countries, South East Asia is another destination for e-waste. The transports of e-waste are partially a result of existing shipping routes, in which Antwerp functions as a port of transit for other (EU) countries, rather than Belgium being the sole source of e-waste. A civil society respondent (S10) was of the opinion that Antwerp functions as "the rubbish tip" ${ }^{37}$ for e-waste and end-of-life vehicles destined for Africa.

The documentary analysis provided a number of facts about e-waste transports with a connection to Antwerp. Data from the Flemish environmental inspectorate [80] revealed that the controlled e-waste exports towards Asia had 13\% of infractions in 2009 compared with $23 \%$ in 2008. According to the inspectorate, this decrease is mainly a result of the decrease in transports from particular expeditors. They were targeted in 2008 for their illegal transports of e-waste and tar containing cable waste. There were increased controls after the media attention ${ }^{38}$ for e-waste transports to West Africa. 21 shipments with destinations in Ghana, Cameroon and DR Congo were controlled in 2009 and 12 of those contained hazardous waste such as monitors and $\mathrm{CFC}^{39}$ containing fridges. In 2010, the federal environmental inspectorate found $35 \%$ of inspected transit units, containers and vehicles, to be in breach of legislation [82]. A study of hazardous waste seizures in Hong Kong [83] mentioned three Belgian shipments of 170 tonnes of used computer monitors, two of which were actually meant for Vietnam. "The seizure of the transit consignment made in June involved nine 40 -foot containers of $125,020 \mathrm{~kg}$ of used computer monitors. It was the largest seizure of used computer monitors in one single consignment, amounting to nearly $49 \%$ of the total quantity of seizures of waste consignments exported from the EU." [83]. This study found Hong Kong to be a transit port, similar to what can be observed about Antwerp. A hazardous waste inspection project in June and July $2010[84,85]$ found e-waste to be the illegal waste type most frequently encountered. These were wrongly declared as second hand goods and contained CFCs or CRT ${ }^{40}$ television sets or monitors while being described as metal scrap. The routes followed were generally from North America to Asia and from Europe to West Africa and Asia. In the annex of this report, INECE lists the shipping routes encountered during the inspections. Belgium is listed there once as a state of export and multiple times as a state of transit ${ }^{41}$.

The amount of (EEE) that was introduced in the Belgian market is another indicator of the scale of ewaste transports. In 2008, a total of 141,194 tonnes of household EEE and 26,686 tonnes of commercial EEE

\footnotetext{
37 Communal waste collection and recycling centre.

38 These media reports exposed the dumping or inhumane 'recycling' of exported 'second hand' fridges, TVs, laptops, PCs, etc. and labelled the port of Antwerp as a true waste hub [57,81].

${ }^{39} \mathrm{CFC}$ stands for chlorofluorocarbon which was used as a refrigerant. The manufacturing has been phased out by the Montreal Protocol because it contributes to the depletion of the ozone layer and is very hazardous.

40 CRT stands for cathode ray tube and these television sets contain a lot of lead (up to $2.5 \mathrm{~kg}$ ), mercury and cadmium and are thus hazardous.

41 These transit flows originated in France, Germany, the Netherlands, Spain, the United Kingdom and Switzerland and went to Nigeria, Tanzania, Ghana, Mali, Ivory Coast, Senegal and Burkina Faso [85].
} 
was introduced into the market of Flanders and about 58,638 tonnes $^{42}$ were collected [86]. A share of the WEEE is first collected in the legitimate recycling systems (e.g. Recupel ${ }^{43}$ ) and then properly recycled. This accounts for about $40 \%$ [86] and is increasing. "The Belgian take-back system is regarded as one of the most effective because the centralized system does away with the risk of a race to the bottom in the separate systems, which are more likely to feed into illegal flows of e-waste" (C18). Although this does not represent the total amount of products introduced into the market, this should not necessarily be regarded as problematic, since the disposal of products does not happen at the same rate. "An estimated $10 \%$ of Belgium e-waste is unaccounted for, either through the official take back system or in other flows. For other European countries, $10 \%$ or more is however known to flow into illegal transports of e-waste" (G14). Now that the scale of e-waste transports has been assessed for both the EU and the Belgian setting, this article continues with an analysis of the emergence and social organisation of illegal e-waste flows.

\section{EMERGENCE AND SOCIAL ORGANISATION OF ILLEGAL TRANSPORTS OF E-WASTE.}

Factors on different levels and segments of the trade flow have the potential to shape illegal transports of ewaste. Earlier publications [3] referred to profit or lure as the major aetiological factors, but this article illustrates how these are key elements yet require further contextualisation. Explanations reside at individual, organisational and societal levels of analysis [35-37]. Both in exporting and importing countries and in supply and demand there are motivations and opportunities for illegal e-waste transports. Their nature and scope is impossible to grasp unless the economic, political, cultural and social context are taken into account [20]. In this article, these are referred to as push, pull and facilitating factors, which together provide the motives and opportunities for actors involved in illegal transports of e-waste. In the analysis of the actors involved, this article follows the flow of the supply chain from producers and consumers through collection and transport to destination, as portrayed in Figure 1. The analysis of the emergence and social organisation of illegal transports of e-waste is thus integrated, because they are inherently intertwined. The actors involved can be producers, distributors, consumers, collectors, refurbishers, waste brokers, shipping companies, recyclers, downstream vendors and actors responsible for final disposal [88]. Figure 1 illustrates the actors that were identified in this case study of e-waste transports in Belgium. In what follows, I will explain which of these actors can be a source of leakage into illegal transports of e-waste. This illustrates how illegal e-waste flows start with the consumers who seek a way to get rid of their no longer functioning television sets, computers, etc., but extends to e-waste collectors, recyclers and refurbishers in developed as well as developing countries. First, the push factors in production and consumption and in e-waste collection are discussed. Next, the facilitating factors in transports are up for discussion. The analysis then moves across

42 This corresponds to about $9.52 \mathrm{~kg}$ per inhabitant. The WEEE-directive asks for a minimum of $4 \mathrm{~kg}$ per inhabitant so this is largely met in Flanders.

43 The WEEE Directive provides a minimum harmonization for producers to take care of the collection and ecologicallysound treatment of their products, which is implemented differently throughout the EU member states [87]. Recupel is the official take-back system for e-waste in Belgium. Consumers pay a fee for environmentally sound disposal when they buy appliances. Recupel uses these funds to collect the e-waste free of charge. 
international boundaries and discusses pull factors in countries of destination. For each of these dimensions, this article analyses whether the legal-illegal interface is antithetical or symbiotic [26]. This will illustrate how the actors and their motivations shape the flows of e-waste on a thin line between legal and illegal.

Figure 1: Actors involved in e-waste transports

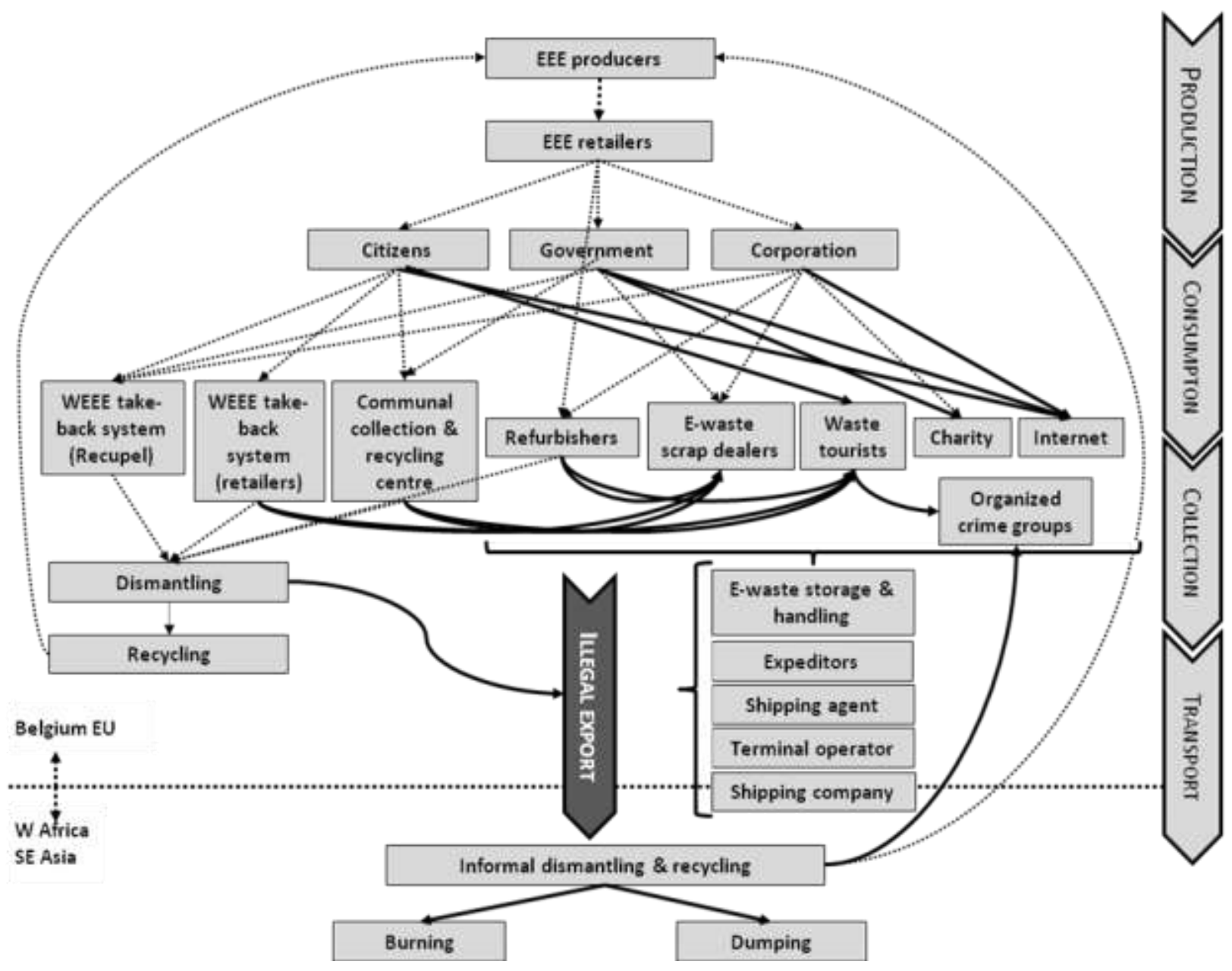

\section{Production and consumption}

The historical development of the (e-)waste problem is the first push factor. The volume of waste has grown due to increased production processes and increased consumption of synthetic products. The digital (r)evolution has resulted in a significant increase in the quantity of e-waste, but also the quality has changed given that hazardous substances are used in EEE [1]. E-waste is one of the fastest growing waste markets [76] and is likely to increase in the coming years given the exponential consumption of EEE [89]. As a consequence of more stringent waste regulations, waste management prices have risen in the industrialised countries, which caused waste to become a global market commodity [90,91]. Exporting the waste is a way to 
externalize the harm and create a distance between producers and consumers, on the one hand, and those affected by the dumping or recycling of the products on the other hand [21].

Rapid high-tech developments lead to regular replacements of EEE. Many people already have a laptop, personal computer and tablet computer, and might still feel the need to buy the newest edition upon release. Consumption patterns are thus contributing to the e-waste problem. Both producers and consumers have a responsibility in this. Producers can first of all ensure the recycling of e-waste is less harmful by phasing out hazardous components ${ }^{44}$ and through eco-design they allow for updates instead of discarding of EEE. Consumers have a responsibility in the economic and ecological consumption of their EEE. Once discarded by consumers, e-waste follows different routes down the flow. The motivations and opportunities to feed into illegal transports of e-waste differ for each group of consumers (citizens, corporations, governments). A major part of e-waste from citizens follows the official take-back system (Recupel) or goes to the communal waste collection and recycling centres. Besides that, a lot of electronics are collected through retailers who are obliged to take in old products when selling new ones. This is at no cost to the retailer, since the take-back system (Recupel) picks up the discarded EEE for free. The costs are integrated into the retail price of the goods and thus paid by the consumer. Citizens may also give e-waste to 'charities' or have it picked up by small-scale informal collectors. Moreover, they throw small electronic appliances into the household waste instead of disposing of them separately ${ }^{45}$. This study did not interview citizen consumers about their involvement in e-waste flows. For insights into their motivations and opportunities, I therefore rely on findings of other studies [71, p.26]. Citizen consumers are found to be mainly influenced by a lack of awareness about both the harmfulness of e-waste and the existence of environmentally sound recycling systems. Moreover, they might not know about their legal rights and responsibilities. In giving the UEEE to charity, or to someone who offers to pick it up, they most likely choose the solutions that seem most comfortable, helpful or profitable for them.

Besides individual consumers, governments and corporations are important consumers of EEE. This commercial WEEE/UEEE is hardly ever collected by Recupel, since the owners can make money out of it or sell it through other channels which guarantee data wipe. Moreover, these actors have a financial incentive to regularly renew their equipment. Both governments and corporations who regularly update their equipment work with contractors who take care of the data wiping, refurbishing and replacement of their equipment [92]. Older equipment is discarded and disposed of using Recupel or waste collection and recycling centres. Sometimes, however, such contractors feed into illegal transports of e-waste. One of the corporate respondents (C20) explained how their awareness of sustainable WEEE solutions was raised as a result of the discovery of their equipment in illegal transports, exposing their corporation to bad publicity. Another corporate respondent (C22) explained how it is vital for them to "not only provide a box to collect e-waste,

44 This is the subject of the EU's Restriction of Hazardous Substances (RoHS) Directive (2002/95/EC).

45 According to a government respondent, the amount of that is difficult to assess, but analysis of household waste has shown to contain small electric and electronic devices (such as computer mouse, earphones, iPods, mp3 players, etc). The report of this analysis is not public yet. 
but make sure you know where the box goes to". According to some corporate respondents the "major threat is with the business and government staff who might be tempted to feed into alternative flows of e-waste" $(\mathrm{C} 18)^{46}$. The following testimony of a corporate respondent (C19) further illustrates how corporations and governments lack awareness or due diligence in matters of e-waste:

It has happened that I arrive somewhere to buy second hand computers a government or corporation wants to dispose of. I offer a certain price they have to pay for the refurbishment, with certified data wipe. Sometimes I can offer them money depending on the quality of the equipment. Many times however these computers or other e-goods are bought for high prices by competitors. I know it can never be profitable to treat or refurbish them in Belgium for these high prices, so it is likely they end up in illegal transports. Their prices are so high that they should ring alarm bells, but in the end it is the consumer who decides who to sell to.

A report by the Dutch inspectorate assumed mainly small and medium-sized enterprises to be involved in this because major corporations are afraid of the reputational damage [68]. The respondents interviewed in this study, however, referred to both small and large-scale corporations. If it does concern large corporations, the quantities are of course likely to be substantially larger. As is evident from the above quotations, the motivations for corporate and government users of EEE to feed into illegal transports of ewaste are profit and a lack of awareness about both the harmfulness of e-waste and the untrustworthiness of some e-waste collectors.

With reference to the legal-illegal interfaces in e-waste flows [26], legal consumers can feed into illegal transports of e-waste, since they interact with actors who offer to treat their e-waste for low prices. These actors can have legitimate business structures (refurbishers, brokers), but could well be "waste tourists" (see below). Consumers are clients of these illegal actors and therefore have a symbiotic relationship with them. It is unclear, however, to what extent this is motivated by a search for cheaper disposal and a lack of awareness about the harmfulness of e-waste and the untrustworthiness of particular e-waste collectors or, on the contrary, by an intentional choice for illegal disposal. When they are unaware about the illegality of it, this could then refer to the synergy interface. When it concerns an intentional choice, this equals the interface of outsourcing, because the dirty work of disposing of the e-waste is done by an illegal actor for a legal actor. Outsourcing is particularly relevant for waste, because it allows legal actors to externalize the harm [29].

\section{Collection of e-waste}

The negative value of waste is deemed to be a key criminogenic characteristic of this economic sector $[20,39,40]$. For a normal commodity, a producer provides the consumer with the product and in return gets the money. For waste, the waste producer gives the waste treatment facility the product as well as the money.

${ }^{46}$ Because these corporations allow this to occur, through a lack of security checks or due diligence, they are what Tijhuis [29] would refer to as 'facilitating interfaces'. 
This inverse incentive structure is therefore a push factor for illegal disposal [32]. However, for e-waste, the picture is more complex and holds a double profit motivation. E-waste includes devices with treatment costs, but some products hold enough valuable components to make recycling or treatment profitable [9]. For the former, exporting them as second-hand products saves the costs of treatment. The latter is a motivation for having the goods dismantled as cheaply as possible to sell the raw materials [64]. Corporations that treat the e-waste legally and have environmentally sound management systems are few and their prices can be high. This makes it attractive to look for cheaper - less environmentally sound - alternatives. The corporate respondents of this study, however, claim it is difficult to make profits when dismantling activities happen in Belgium, given the high labour costs. Therefore, they said, it was unlikely for actors to make a profit from ewaste recycling even when the e-waste is accepted for free. When money is offered for e-waste, they believed this to be suspicious and likely to be leading to illegal exports. "You can make money by 'recycling' e-waste in poorer environmental and social conditions, since this provides you the precious metals with lower labour costs." (C13). Similar results were found in previous research [2].

Another push factor for illegal transports is the complexity of the e-waste flows and the competitiveness of the market. Many sub-streams of waste arise from the dismantling of these products and there are multiple actors involved in e-waste collection. It involves metal scrap dealers, urban recycling centres, official take-back systems (e.g. Recupel), registered metal collectors (e.g. picking up disposal skips from electronic hardware stores) and informal actors (e.g. waste tourists, internet or charities (see Figure 1). Many of these e-waste collectors and recyclers live up to their espoused environmental and ethical standards and regard illegal transporters of e-waste as their biggest competitors. Other organisations that claim to recycle EEE are less honourable and engage in direct or indirect export - often through brokers - to developing countries. "E-waste is prone to fraud, because many actors can buy and sell, often as their sole means of income." (C11). The potential leakages in e-waste collection identified in this case study are now discussed in turn.

In communal waste collection and recycling centres some might be tempted to sell an e-waste load outside the official system. Similarly, retailers could be tempted to sell a container instead of having it picked up for free by Recupel. These retailer collection points do not keep accurate waste registers, which makes it difficult to determine the exact amount of e-waste collected. Whether these buyers of e-waste follow the efficient and registered recycling flows is unclear. Both retailers and communal waste collection and recycling centres could also fall victim to e-waste theft. ${ }^{47}$ These are grey areas which could result in illegal transports of e-waste towards developing countries.

The Belgian take-back system is perceived as an effective system that guarantees legal disposal and recycling. However, respondents have mentioned there is a parallel flow of particular products (e.g. mobile phones) that is completely out of sight of the official take-back system. Other European countries moreover have different take-back systems, which are not monopolies as is the case in Belgium. According to

\footnotetext{
${ }^{47}$ The corporate respondents have told me that containers are regularly emptied by thieves.
} 
government and corporate respondents, these take-back systems are not as effective because they require producers and retailers to take care of the recycling, hence they are more likely to choose cheaper alternatives. This partially explains why $80 \%$ of the e-waste that passes through Antwerp originates outside Belgium.

Refurbishers are other actors that take care of e-waste collection. This sector buys electronic devices from firms or government agencies - or universities for that matter - that change their computers every three to five years. Retailers deliver damaged goods to them directly. These goods are repaired, refurbished and the remains are recycled. Refurbished goods are sold to schools or development projects in industrialised and developing countries or simply sold to individual consumers who do not need the latest technology. These goods are shipped legally to countries outside the EU, mostly in large mono-consignments. In this way, refurbishers try to make their business in a niche sector. "The business model of retailers is focused on selling, not on the reverse logic of take-back. This is where we try to make a difference." (C21). These professional refurbishers are keen to show they work legally and therefore have a policy of transparency. This allows responsible authorities to check them whenever necessary. Not all refurbishment companies choose these environmentally and socially just paths, however. A proportion of these refurbishment goods "disappear" through networks of scrap dealers, waste tourists and e-waste brokers. Even Belgian government computers are thought to have ended up in developing countries illegally ${ }^{48}$.

Some e-goods are donated to charity and sent to development projects abroad. Whether these computers arrive there or whether these transports answer to the quality requirements is unsure. Other initiatives collect mobile phones and donate, for instance, 1 euro per phone to charity, but once again it is not clear where the collected UEEE/WEEE goes to. Some websites also offer to buy UEEE (e.g. mobile phones) for a small price or offer to pick WEEE up for free. Sometimes these websites link back to known refurbishers or collectors, other times the organisations or individuals behind it are unknown.

During my field visits to Ghana, several importers and UEEE shop owners explained how they guarantee supplies. What happens is that "waste tourists" buy or collect the e-waste. These informal actors might be EU residents or have a tourist visa. They collect the "second-hand goods", load a container or a truck and travel back to the country of destination to wait for their shipment ${ }^{49}$. Some of these waste tourists live in the countries of origin and cooperate with relatives in the countries of destination to pick up the transport. According to corporate, government and civil society respondents, these waste tourists can be more organised than they might seem: the same people re-emerge and are interconnected through business-like structures of collectors in European countries, transporters and recyclers or sellers of second-hand goods in West Africa. A Ghanaian terminal operator revealed he has several clients that ship approximately 20 containers of UEEE/WEEE per month. According to the Belgian government respondents, it is difficult to track them down because they usually have false passports under different names. Some of the government respondents expressed their concern that this might be linked to organised crime and Ghanaian civil society

48 A study by BAN [10] mentions that Belgian computers have ended up in Ghana.

${ }^{49}$ See, for instance, the report by the Dutch Inspectorate VROM [68] 
respondents mentioned Chinese, Nigerian and eastern European organised crime in particular. This is consistent with the findings of Europol's latest organised crime threat assessment [93] which explains how illicit waste trafficking is often facilitated through the cooperation of organised crime groups with legitimate businesses and how both northern and southern European ports act as hubs for illegal waste.

In the last couple of years, the respondents have witnessed the increasing importance of the internet for e-waste collection. The same goes for "new for old" swaps in stores. "E-goods collected over the internet and in stores may end up in good treatment or recycling facilities, but a share of it gets lost and transported to Africa. It is difficult to know whether the good quality or bad quality goods end up in Africa." (G15).

Metal scrap dealers play a role as intermediaries in the collection of e-waste. They buy discarded electronics and often already disassemble those to sell the metal content. These might then still end up with the same recyclers the official take-back system uses. However, because the threshold to collect WEEE within the official system is high (e.g. licenses, equipment), small-scale scrap dealers now risk flowing into illegal transports. "They aren't all criminals but they sure do facilitate a lot" (GE14). Sometimes the recycling facilities in Belgium are intermediaries when components require manual separation after passing through the smelter [64]. Both government and corporate respondents have confirmed that these are shipped to Asia for manual dismantling after the smelting process is complete. These transports are legal because this is a non-hazardous activity.

Other intermediaries are facilities for waste storages and handling. These storage facilities receive ewaste or used goods of different quality and mix those up in the overseas shipments. Once again it is important to stress that $80 \%$ of all e-waste that passes through the port of Antwerp originates in other countries other than Belgium. Located in the Brussels area and locations closer to the port of Antwerp, these brokers receive e-waste by rail or road transport from other countries (e.g. Germany, the Netherlands or France). According to a government respondent (G27), these businesses and their suppliers re-emerge: "The invoices that are meant to prove the origin of the goods are often identical and contain hardly any information, with the intent to hamper controls." 50 These waste storage and handling facilities buy and sell the waste and are actually already a transport actor, which is the topic of the next section.

E-waste collection by waste tourists, for charity and over the internet, could all be perceived as the activities of illegal actors who compete with the legal market, thus constituting an antagonistic interface. Similarly illegal e-waste brokers are competitors and they might even aim to put other collectors out of business (predatory). Some of the e-waste collectors are however intermediaries in legal transactions as well and therefore promote similar interests to the illegal collectors of e-waste. This fits a symbiotic nature of the legal-illegal interface. When there is an unconscious involvement in illegality, it is an interface of synergy. In case they do know about the illegality, this interface is either one of collaboration in the case of long term links or one of reciprocity for shorter term but still mutual benefits. One last leakage and illegal-legal interface

50 van Duyne observed similar structures for invoicing and transportation in a Dutch-Belgian case of illegal waste transport and dumping [32] 
occurs when retailers as well as communal waste collection and recycling centres are the victims of e-waste theft. This could be perceived as an injurious legal-illegal interface.

\section{Transports of e-waste}

Containerization saves cost and time and has facilitated the rapid growth of legitimate international trade in recent decades [94], but the anonymity of containers offers particular advantages for organisations wishing to transport illicit commodities [95,96]. Shipping a container to Africa or South-East Asia is cheap, making it a low threshold for illegal transports. "These ships are so to speak waiting in the port to be loaded again after unloading all the processed goods (e.g. clothes, electronics, cars, etc. from China) and raw materials (e.g. cocoa, fruit, metals, timber, etc. from Africa)." (C1). Different actors have a role to play in the transports and can thus be tempted by these facilitating factors (see Figure 1).

Port authorities play a role. On the one hand, they are mainly interested in filling the containers and sending them back to Africa and Asia. On the other hand, they are responsible for port safety and can in this way indirectly influence e-waste transports. As an example, the Antwerp port authority, harbourmaster's office, the waterway police and inspectorates have drafted a regulation ${ }^{51}$ for the transport of additional cargo in second hand vehicles and imposed stricter controls. One of the reasons for this was that e-waste smugglers had started using cars, vans and trucks to transport waste as a countermeasure to the increased controls on containers $^{52}$. The new regulation requires a bill of lading for the extra load in vehicles and there are stricter loading instructions. This new regulation is however under pressure because the end-of-life vehicles are a major commodity for the port, which might see this economically significant activity relocated to other ports. The port authorities and state actors might simply be shaping the structural context for these flows, but could be interpreted as facilitating illegal activities [97].

Terminal operators load and unload the goods on the ships. They are generally not concerned with the legality of the goods, but merely with the safety of the operation. Shipping lines are in a similar position [64]. "The shipping lines will often go with 'I don't know, no idea what's inside', but they know many of their customers and could be more responsible about who they allow through a use of black lists" (G19). Some civil society respondents have revealed that the port of Antwerp logistics is thriving on mafia business, but it is hard to interpret these comments. Certain shipping lines are alleged connected to the Italian mob, but hard proof is lacking.

An important role is played by shipping agents. They arrange the transports over road or inland waterways to the nearest port and take care of the handling of the goods in the port. Those expeditors are not always brokers because they do not necessarily buy the waste, but might simply arrange the transports. Shipping agents usually do not engage themselves with the content of the transports and merely arrange the

51 Regulation of 24 November 2011 for handling of second hand vehicles in the Port of Antwerp (Reglement voor het behandelen van tweedehands voertuigen in de haven van Antwerpen) - Entered into force 1 January 2012

52 A baseline assessment of the cars shipped from the port of Antwerp found out that 5-10\% of vehicles contained ewaste. With about 400,000 vehicles shipped annually and $10 \%$ of those originating in Belgium, this means $4-8,000$ vehicles are loaded with e-waste in Belgium each year. 
paperwork. Through this activity however, they facilitate illegal transports. "Despite the requirement in the WSR for expeditors to provide information about the destination of the goods, the expeditors hide behind commercial secrecy and are hesitant about giving away the information about the destination ${ }^{53}$. They only fill out [documentation with] the information they get, not all they know and in this way they keep the traffic in place. Their clients deliberately withhold information about the address of the disposer, but expeditors allow them to." (G14)

Shipping lines and terminal operators have e-waste smugglers as clients, either in container or in vehicle transports. This fits a symbiotic nature of the legal-illegal interface [26] because legal actors work for illegal actors, but it is unclear to what extent the former knowingly collaborate. In case they do not know, this interface is one of synergy. In case they do know, this interface is either one of collaboration in case of long term links or one of reciprocity for shorter term but still mutual benefits. Similar to shipping lines and terminal operators, expeditors and shipping agents have smugglers as their clients, but their involvement is deemed to be more deliberate: "If the shipping agent fills out the waste goods codes correctly, it will never pass the customs system without a check." (G22). They can at least be accused of a lack of due diligence or of culpable negligence because of withholding of information. Similarly the synergy, collaboration or reciprocity interfaces apply.

\section{Countries of destination}

A fourth segment in reference to the e-waste flows (see Figure 1) is of a different nature. Rather than factors that push or facilitate the flows of e-waste, factors that attract e-waste flows are analysed. Although this should not be overplayed, the institutional framework in countries of destination - or lack thereof - is a first pull factor [88]. Although some studies [80 ${ }^{54}$ perceive this to be of low risk due to its clarity, consistency and good quality, others believe the massive amount of regulation on waste indeed leaves only limited blind spots, but does hold a risk of causing confusion and liability problems [90]. Moreover, "stringent regulation and control creates extra motivation for bypassing the law and often provides those crooks with bigger profits." (C15). This refers not only to their weak regulatory system or government, often as a result of wars or conflicts, but also their precarious socio-economic situation. This causes them to allow e-waste shipments to be imported into their country, because of their financial attractiveness [6]. Imports of e-waste are a way to increase their revenue (through taxes), which is referred to as garbage imperialism [1].

EEE discarded by industrialised countries may represent the sole secure source of livelihood for many people in developing countries, constituting a second pull factor. These economies-in-transition and developing countries have a massive formal as well as informal economy thriving on the repair, refurbishment, dismantling and recycling of second-hand EEE. These informal actors are wary of the term "e-

\footnotetext{
53 Annex 7 to the WSR is problematic here, since this allows the original sender and receiver of the goods to be disguised.

${ }^{54}$ A 2010 study commissioned by the Flemish Inspectorate for the Environment analysed different waste streams and their risk profiles. To arrive at the risk profiles they weighted risk factors (legislation, market and context, technique, costs, criminogenic factors) on a scale from 1 to 5,1 being the lowest risk, 5 the highest.
} 
waste", because these "used goods" are the only guarantee of livelihood for many [78,98]. As I witnessed in the field (Agbogbloshie dump, Accra) many devices or cables are simply burned to remove the plastic casing and collect the metals. Scrap collectors - known as scavengers - collect valuable waste on the streets and the well organised informal recycling sector dismantles the devices and sorts valuable and non valuable components [99]. In Ghana, the informal sector is estimated to generate 100 to 250 million US dollars per annum and employs 22,000 people in Accra alone [78 ${ }^{55}$. An estimated $0.82 \%$ of the total Ghanaian population have informal WEEE repairs or refurbishing as their sole means of livelihood. Second-hand - but also non-working - television sets, computers, mobile phone (batteries), etc. are sold on many street corners. In China, the millions of jobs in the informal sector are a motivation for the government not to tackle the illegal shipments of e-waste too harshly, according to an NGO-respondent (S12). Stopping the flow of e-waste would take away the supply for these informal sectors and is likely to cause social unrest. One corporate respondent (C18) said: "The big recyclers in Europe are likely to disagree, but some recyclers abroad are equally well equipped and exports to these countries are more economical given the proximity of the production sites".

Besides guaranteeing a livelihood for many people, the digital divide creates a hunger for technology in developing countries. This is a third pull factor. E-waste transports can help bridge this divide since computers, mobile phones and other electronic devices allow people to catch up with global developments in knowledge and communication. "Importers seem willing to bring in containers mostly filled with e-waste because the demand for electronics is so high that buyers are prepared to purchase untested items." [76, p.2]. It is however important to be mindful about the consequences of bridging this digital divide. Inadequate treatment of e-waste flows can have detrimental effects for environmental and human health as well as for the economy and politics. The developing countries end up with the old technology and with the waste. One of the Ghanaian civil society respondents (S16) referred to this as "bridging the digital divide by creating a digital dump".

The informal e-waste collectors and "recyclers" feed into the legal e-waste industry through the increased demand for secondary raw materials, which is a fourth pull factor. The pressure on natural resources plays a role in market dynamics and is likely to become increasingly important in future geopolitics. One way of guaranteeing the inflow of (precious) metals into natural-resource poor Europe is by exploiting the resources of the urban mine ${ }^{56}$ to their full potential. There is however a major pull for e-waste

55 Formally registered businesses import EEE on a regular basis and mostly focus on one particular product (e.g. refrigerators, PCs, etc.). $70 \%$ of those imports work, $20 \%$ can be repaired (but often only functional for another 1 or 2 years) and 10\% does not function. Informal importers are unregistered business owners, mostly residents of foreign countries who import one or two 2 containers per year. Some of this EEE is bought from refurbishment companies and therefore tested for functionality; other EEE imports are not tested however. Of these informal imports, $60 \%$ are functioning, $20 \%$ can be repaired (once again with a short lifespan remaining), and $20 \%$ is simply e-waste [78]. Another way EEE enters the country is through private imports (in the luggage of individuals) or through donations (which are exempt from tax).

56 The urban mine is a mine of (raw) materials from products, buildings and waste in a society. Urban mining is the idea of using those compounds and elements as resources for new production, thereby avoiding these materials from going to waste. E-waste exports can thus be seen as a loss in raw material. 
transports to Asia. The spotlights have been on China and India, and the situation in terms of illegal e-waste transports seems to have improved somewhat. China has stricter laws ${ }^{57}$ on e-waste, which prohibit import unless it is useable as raw materials and unless the requirement of prior consent is met. In practice however these imports are still tolerated and sometimes documents refer to unknown or unlicensed treatment facilities. The extracted components or metals still end up with the same producers, mainly in India and China, after dismantling and 'recycling' in Africa, Vietnam, northern China and Cambodia. Repair, refurbishing, reselling, recycling and dismantling happens in small workshops which are supplied by informal collectors (hawkers, pedlars, individual vendors) [100]. Although these recycling facilities are increasingly well equipped [20], the limited number of official recycling facilities in China does not provide enough materials for their smelters. However, informal dismantlers in some regions (e.g. Accra) are said to be improving both environmental and labour standards and "moving away from the one-sided bad story, because a lot of progress has been made" (S21). Local NGOs in Ghana motivate dismantlers not to burn the ewaste by not buying the burnt copper. Other actors however, accept all metals, burnt or not, and this perpetuates the burning.

Similar to their involvement in countries of origin, organised crime groups were mentioned to be involved in the collection of metal scrap on waste dumps in West Africa. In particular, the respondents referred to organised crime groups of Nigerian, Italian, Eastern European and Chinese origin who collect the valuable materials from informal workers on the dump and sell them as secondary raw materials on the global metal market. This is consistent with findings by Gonzales, Schofield and Hagy [101] which state that Asian organised crime groups are expanding their influence to legitimate business such as waste disposal. As an Agbogbloshie worker put it: "I sell copper to Chinese men and mother boards to a white man from Europe".

The interface in countries of destination is both legal and illegal, formal and informal. Informal collectors and dismantlers compete on the same market as formal actors, and even organised crime. This implies an antagonistic interface and might even be aimed to extort (parasitical interface) or destroy (predatory interface) other actors. There is another legal-illegal interface that presents itself. The raw materials that were extracted by informal actors feed into the legal production. Sometimes organised crime acts as a go between in this. This constitutes an interface of reciprocity or collaboration between legal, illegal and informal actors. On the supply side, these informal dismantlers as well as sellers of second hand e-goods cooperate with both illegal (e-waste) and legal (used goods) transporters. It is not easy to determine whether this last category of actors is legal or illegal. Legal recycling actors face competition (antagonistic interface) from governments that tolerate the imports of e-waste (against national or international regulation). These governments support informal or illegal dismantling or recycling actors, constituting a (non-financial) funding interface. Legal actors might thus be facilitating and even initiating crime [97], but the line is difficult to draw. The transports of e-waste are not allowed, but they do provide a stable (and sole) source of income

${ }^{57}$ SEPA Document No. 19/2000 of January 242000 'Notification on import of the seventh category of wastes' 
for many. Throughout the flows, the status of e-waste can actually change between legal and illegal multiple times. Once EEE is dismantled, refined or comes out of a smelter, there is no way of tracing where it came from, which implies it may feed into the legal industry again.

\section{DISCUSSION}

Reference to illegal markets might immediately bring to mind pictures of organised crime syndicates on national or international levels. Illegal market activity does not necessarily refer to these mafia-like organisations, however, but to situations where business or government actions are on a thin line between legal and illegal $[102,103]$. This article aims to provide insights into the social organisation of illegal transports of e-waste to achieve a more complete view of the network of actors involved in them, which in turn can progress theory on transnational environmental crime [32,30]. This study asked the question which legal and illegal actors are involved and whether their interaction is of a symbiotic or antithetical nature. The results presented different kinds of legal-illegal interfaces. At the start of the flow, consumers sometimes sell their e-waste to actors who offer to treat it for (too) low prices. Whether this is due to a lack of awareness and due diligence or a conscious choice for cheaper illegal disposal, both cases constitute a legal-illegal interaction in which government, as well as corporations and individual consumers can be involved. Depending on the legal actors' awareness of the illegality, this interface is either one of synergy or outsourcing. This outsourcing particularly applies to the case of e-waste, because this allows the legal actor to externalize the harm. Further down the flow, e-waste collection has various potential interfaces between legal and illegal. Waste tourists, and collection of waste for charity and via the internet, are illegal sources of e-waste that compete with the legal market (antagonistic interface). E-waste brokers are on an even more complex legal-illegal nexus. On the one hand, they have a role as legal intermediaries in transactions and therefore promote similar interests as the other actors in collection of e-waste. On the other hand, through waste storage and handling these brokers function as intermediaries for illegal transports. Depending on whether this is a knowing or a longterm involvement in illegality, this is an interface of synergy, collaboration or reciprocity. Other legal actors in e-waste collection are scrap metal dealers and refurbishers. Some of those are however known to (intentionally) feed into illegal transports. Besides these legal-illegal interfaces in e-waste collection, actors can be on a thin line between legal and illegal in transport of e-waste. Shipping lines, terminal operators, expeditors and shipping agents all have e-waste smugglers as their clients. The involvement of the first two seems to be one where they can be accused of a lack of due diligence (synergy interface), whereas the last two sometimes play a more deliberate role in facilitating illegal transports of e-waste (collaboration or reciprocity interface). At the end of the e-waste flows - in countries of destination - the line between legal and illegal may be even more difficult to draw. Informal collectors and dismantlers compete on the same market as formal actors and organised crime, and cooperate with legal actors by selling them the extracted secondary raw materials. This implies an antagonistic interface and might even be aimed at extortion (parasitical interface) or destruction (predatory interface) of other actors. Moreover, informal dismantlers and sellers of second 
hand e-goods in countries like Ghana cooperate with both illegal (e-waste) and legal (used goods) transporters. Governments in countries of destination that tolerate the import of e-waste - against national or international regulation - are competing with the legal actors in countries of origin. These countries of destination thus witness interfaces of reciprocity or collaboration between legal, illegal and informal actors. These could be categorized as facilitating and maybe even initiating crime [97], but it is not all black and white: although the imports of e-waste are illegal, they provide many inhabitants with a stable source of income or access to the digital age. Moreover, informal dismantlers in some regions (e.g. Accra) are said to be improving both environmental and labour standards. In sum, legality and illegality is not clearly depicted when talking about these actors.

The analysis of the social organisation of illegal transports of e-waste makes clear that the powerful are not necessarily knowingly involved in transnational crime or deliberately crossing the line from legal to illegal. There is however at least a lack of due diligence on the part of some actors. Take the example of government agencies and corporations in countries of origin that sell e-waste for prices which should ring alarm bells. A major part of the trade is in legal hands, but this legal character is easily stretched or shed and constantly in evolution. It is therefore difficult to give these transports of e-waste an unambiguous legal or illegal label since they are a result of a multitude of legal-illegal interfaces. E-waste is part of the legal economy, but meanwhile prompts different kinds of illegalities [39,104]. Recycling e-waste, especially in developing countries, can be on a thin line between environmental sustainability and disregard of environmental and labour standards. A shipment of good quality second-hand EEE to most non-OECD countries is legal ${ }^{58}$ and a shipment of damaged or non-functioning goods is illegal. In the eyes of the beholder this illegal e-waste shipment might still be worth more than Northern actors would imagine. In addition, the thin line between legal and illegal is apparent in the definition of what e-waste is and what constitute used goods or recyclables. One respondent (C13) illustrated that by remarking: "What is listed as waste is often the cleanest thing that's shipped." E-waste is a massive industry, with recycling, second-hand EEE, parts, fixing, refurbishing, etc.; only a part of it is truly going to waste. The bottom line, however, is that these practices regardless of whether the transports are legal or illegal - cause harm to humans and the environment, because there are no adequate e-waste recycling facilities in Ghana (or in West Africa). Legal transports of second hand goods might have equally detrimental effects. Trade laws sometimes allow the exploitation of nature for consumption and production processes and continue the externalization of harm and risk $[105,106]$. These actions mostly remain off the political agenda, rendering them neither illegal nor criminal [107]. Taking environmental harm as a frame of reference for the legal and illegal flows of e-waste - and by extension other transnational environmental crimes - could overcome the challenge of the thin line. Therefore, it is crucial to focus not only on the strict crimes of illegal waste transports - the breaches of international and national legislation - but also on those activities that are on a thin line between legal and illegal.

${ }^{58}$ A number of Asian countries (e.g. Vietnam) refuse the import of second hand monitors and computers 
The causes of transnational crimes are often neglected or reduced to a mere focus on the profits or greed of a few bad apples instead of looking at potential systemic causes [103]. Although profit or lure are major aetiological factors, this article illustrates how other push, pull and facilitating factors provide the necessary contextualisation for these arguments. It does so by paying attention to individual, organisational and societal levels of analysis and motivations and opportunities of actors in locations of origin, transit and destination. This article illustrates that e-waste is not only about the "big fish", globalization and the corporate dimension, although the corporate and economic rationale remains crucial in understanding the illegal flows of e-waste. It is essential to analyse the economic dimension of the phenomenon on a global scale, since waste is not contained in one country or continent. The importance of transit for e-waste flows in Antwerp is a clear illustration of this, with just $20 \%$ Belgian e-waste and the remaining $80 \%$ inflows from abroad. This illustrates how the open and global market results in illegal cross-border mobility. However, push, pull and facilitating factors on other levels than economy also need to be taken into account. Producers, consumers, waste collectors, transporters and (informal) recyclers - actors big and small, legal and illegal, powerful and powerless all have motives and opportunities that jointly influence (illegal) transports of ewaste. This article illustrates how a criminological analysis of illegal transports of e-waste inevitably encounters economic, cultural, political and social motives and opportunities that together determine the flows $[84,108]$. This entanglement makes it difficult to draw a line between what is or should be illegal. The challenge lies in "protecting vulnerable countries from unwanted hazardous waste imports, while not precluding the import of wastes considered valuable secondary raw materials to countries in a position to manage them in an environmentally sound manner" [109].

The various actors involved in e-waste flows and their diverging motivations and opportunities require a governance framework that is equally diverse and flexible. Initiatives to heighten awareness about e-waste throughout the flows - from production and over consumption to collection, transport and recycling - combined with national and international governmental control and self-regulation are necessary ingredients of this governance mix [3,19,20]. Given the global dimensions of transnational environmental crime, limiting this to national policy is to no avail [22]. However, the local impact should not be neglected either because illegal transports of e-waste may result in harm to environmental and human health, but they might also have positive effects locally (secure livelihood, bridge digital divide). This implies that policy needs to take both the global and the local into account. Future studies should look at the exact implications of these characteristics for the governance framework of transnational environmental crime.

\section{LIMITATIONS}

What this article attempted is to make the phenomenon of illegal transports of e-waste more visible, to get a more complete view of the network of actors, their interactions and their motivations and opportunities, grounded in empirical data. This case study is necessarily connected to its research setting and does not have the intention to provide generalizable results. This method however provides insights that help understand 
the social organisation and emergence of illegal transports of e-waste in other locations as well [110]. These empirical findings provide the necessary input for theoretical developments. This case illustrates how the nature of the goods can be on a very thin line between legal and illegal and therefore complicates the legalillegal interfaces in transnational environmental crime. Future research should focus on other transnational environmental crime phenomena and see whether similar observations apply.

\section{CONCLUSION}

By analysing the case of illegal transports of e-waste in a European trade hub, this article responds to the call for more empirical knowledge about transnational environmental crime. The data analysis revealed different legal-illegal interfaces throughout the e-waste flows. Governments and corporations as well as individual consumers can contribute to illegal transports of e-waste. Actors in e-waste collection were shown to be on a legal-illegal interface. Transport actors can equally walk on a thin line between legal and illegal by facilitating illegal transports of e-waste. Legal and illegal transports were even more difficult to distinguish in countries of destination. Although profit or lure play a very important role, this article shows how push, pull and facilitating factors on individual, organisational and societal levels together provide the motivations and opportunities for illegal transports of e-waste. This demonstrates how the social organisation and emergence of transnational environmental crime is on a thin line between legal and illegal that needs to be contextualised within the global reality of origin, transit and destination locations.

\section{ACKNOWLEDGMENTS}

I am grateful for the research funding of University College Ghent. I thank the members of my doctoral guidance committee (Prof. Paul Ponsaers, dr. Gudrun Vande Walle, Prof. Tom Vander Beken and Prof. Wim Huisman), one of my respondents and the anonymous reviewers for their invaluable comments on earlier versions of this article. For reasons of anonymity I do not name my respondents, but I am indebted to them for answering my questions and for guiding me through their world, in Belgium, Ghana or elsewhere.

\section{REFERENCES}

1. Pellow, D. (2007). Resisting global toxics: Transnational movements for Environmental Justice. Cambridge, MA: MIT Press.

2. Interpol (2009). Electronic waste and organized crime. Assessing the links. Phase II report for the Interpol Pollution Crime Working Group. (pp. 49): Interpol.

3. Gibbs, C., McGarrell, E. F., \& Axelrod, M. (2010). Transnational white-collar crime and risk. Lessons from the global trade in electronic waste. Criminology \& Public Policy, 9(3), 543-560.

4. EMPA (2009). Ewasteguide.info: Hazardous Substances in e-Waste. file://D:/My\%20Documents/PhD_transnatenvironmcrime\&governance/Hazardous\%20Substances \%20in\%20e-Waste\%20\%20\%20ewasteguide.info.htm. Accessed 23 August 2011.

5. Baker, E., Bournay, E., Harayama, A., \& Rekacewics, P. (2004). Vital Waste Graphics: Basel Convention, GRID, UNEP and DEWA Europe. 
6. BAN, \& SVTC (2002). Exporting harm: The high-tech trashing of Asia. Seatlle - San Jose: The Basel Action Network (BAN) - Silicon Valley Toxics Coalition (SVTC).

7. EEA (2009). Waste without border in the EU? Transboundary shipments of waste. Copenhagen: European Environment Agency.

8. Greenpeace (2008). Chemical contamination at e-waste recycling and disposal sites in Accra and Korforida, Ghana. Greenpeace Research Laboratories.

9. LNE (2010). Afvalstromen in Vlaanderen: risicoprofiel. Brussel: Leefmilieu, natuur en energie (LNE).

10. BAN (2005). The Digital Dump. Exporting Re-use and Abuse to Africa. Seatlle: The Basel Action Network (BAN).

11. Greenpeace (2008). Poisening the poor. Electronic waste in Ghana. Amsterdam: Greenpeace International.

12. Sepúlveda, A., Schluep, M., Renaud, F. G., Streicher, M., Kuehr, R., Hagelüken, C., et al. (2010). A review of the environmental fate and effects of hazardous substances released from electrical and electronic equipments during recycling: Examples from China and India. Environmental Impact Assessment Review, 30(1), 28-41, doi:10.1016/j.eiar.2009.04.001.

13. Quadri, S. (2010). An analysis of the effects and reasons for hazardous waste importation in India and its implementation of the Basel Convention. Florida Journal of International Law, 22(3), 467.

14. Halsey, M. (2004). Against 'green' criminology. British Journal of Criminology, 44(4), 833-853.

15. South, N. (1998). A green field for criminology: a proposal for a perspective. Theoretical Criminology, 2(2), 211-233, doi:10.1177/1362480698002002004.

16. White, R. (2003). Environmental issues and the criminological imagination. Theoretical Criminology, 7(4), 483-506.

17. Bisschop, L. (2011). Transnational environmental crime: exploring (un)charted territory. In M. Cools, B. De Ruyver, M. Easton, L. Pauwels, P. Ponsaers, T. Vander Beken, et al. (Eds.), EU Criminal Justice, Financial \& Economic Crime: New Perspectives, Governance of Security Research Papers (Vol. 5, pp. 155-183). Antwerpen: Maklu.

18. Gibbs, C., Gore, M. L., McGarrell, E. F., \& Rivers, L. (2010). Introducing Conservation Criminology: Towards Interdisciplinary Scholarship on Environmental Crimes and Risks. British Journal of Criminology, 50(1), 124-144, doi:10.1093/bjc/azp045.

19. Stretesky, P., \& Lynch, M. (2009). Does self-policing reduce chemical emissions? The Social Science Journal, 46(3), 459-473.

20. van Erp, J., \& Huisman, W. (2010). Smart regulation and enforcement of illegal disposal of electronic waste. Criminology \& Public Policy, 9(3), 579-590.

21. White, R. (2011). Transnational environmental crime. Towards an eco-global criminology. London \& New York: Routledge.

22. Aas, K. F. (2007). Analysing a world in motion - Global flows meet 'criminology of the other'. Theoretical Criminology, 11(2), 283-303, doi:10.1177/1362480607075852.

23. Sheptycki, J., \& Wardak, A. (Eds.). (2005). Transnational and comparative criminology. London: Glasshouse Press.

24. Vig, N. J., \& Faure, M. G. (Eds.). (2004). Green giants? Environmental policies of the United States and the European Union Massachussets Institute of Technology.

25. van der Pijl, Y., Oude Breuil, B. C., \& Siegel, D. (2011). Is there such a thing as 'global sex trafficking'? A patchwork tale on useful (mis)understandings. Crime, Law and Social Change, 56(5), 567-582.

26. Passas, N. (2002). Cross-border crime and the interface between legal and illegal actors. In P. van Duyne, K. von Lampe, \& N. Passas (Eds.), Upperworld and underworld in cross-border crime (pp. 11-41). Nijmegen: Wolf Legal Publishers.

27. Szasz, A. (1986). Corporations, Organized Crime and the Disposal of Hazardous Waste: An Examination of the Making of a Criminogenic Regulatory Structure. Criminology, 24(1), 1-27.

28. Nelken, D. (2002). White Collar Crime. In M. Maguire, M. Morgan, \& R. Reiner (Eds.), The Oxford Handbook of Criminology (3rd ed.). Oxford: Oxford University Press.

29. Tijhuis, A. (2006). Transnational crime and the interface between legal and illegal actors. The case of the illicit art and antiquities trade. Leiden: NCSR.

30. Huisman, W., \& Vande Walle, G. (2010). The criminology of corruption. In G. de Graaf, P. von Maravic, \& P. Wagenaar (Eds.), The good cause. Theoretical perspectives on corruption (pp. 115-145). Leverkusen: Burdich Publishing. 
31. Passas, N. (2003). Cross-border Crime and the Interface between Legal and Illegal Actors. Security Journal, 16(1), 19-37.

32. van Duyne, P. (1993). Organized crime and business crime enterprises in the Netherlands. Crime, Law and Social Change, 19(2), 103-142.

33. Rock, P. (2002). Sociological theories of crime. In M. Maguire, M. Morgan, \& R. Reiner (Eds.), The Oxford Handbook of Criminology (3rd ed.). Oxford: Oxford University Press.

34. Van Dijk, J., Sagel-Grande, H., \& Toornvliet, L. (1996). Actuele criminologie. Lelystad: Koninkljke Vermande.

35. Clinard, M., \& Yeager, P. (1980). Corporate crime. New York: Free Press.

36. Huisman, W. (2001). Tussen winst en moraal: Achtergronden van regelnaleving en regelovertreding door ondernemingen. Den Haag: Boom Juridische Uitgevers.

37. Slapper, G., \& Tombs, S. (1999). Corporate crime. . Essex: Pearson Education Limited.

38. Coleman, J. (1987). Towards an Integrated Theory of White-Collar Crime. American Journal of Sociology, 93(2), 406-439.

39. Vander Beken, T. (Ed.). (2007). The European waste industry and crime vulnerabilities. Antwerpen: Maklu.

40. Van Daele, S., Vander Beken, T., \& Dorn, N. (2007). Waste management and crime: regulatory, business and product vulnerabilities. Environmental Policy and Law, 37(1), 34-38.

41. Klima, N. (2011). The goods transport network's vulnerability to crime: opportunities and control weaknesses. European Journal on Criminal Policy and Research, Online First - 9 february 2011.

42. Vander Beken, T., \& Van Daele, S. (2008). Legitimate business and crime vulnerabilities. International Journal of Social Economics, 35(10), 739-750.

43. Passas, N. (1999). Globalization, criminogenic asymmetries and economic crime. European Journal of Law Reform, 1(4), 399-423.

44. Passas, N. (2000). Global Anomie, Dysnomie, and Economic Crime: Hidden Consequences of Neoliberalism and Globalization in Russia and Around the World. Social Justice, 27(2), 16-44.

45. Ruggiero, V. (2009). Transnational Crime and Global Illicit Economies. In E. Wilson, \& T. Lindsey (Eds.), Government of the Shadows. Parapolitics and Criminal Sovereignty (pp. 117-129). New York: Pluto Books.

46. Antonopoulos, G. A., \& Winterdyk, J. (2006). The Smuggling of Migrants in Greece. European Journal of Criminology, 3(4), 439-461, doi:10.1177/1477370806067912.

47. Morselli, C., Turcotte, M., \& Tenti, V. (2011). The mobility of criminal groups. Global Crime, 12(3), 165-188, doi:10.1080/17440572.2011.589593.

48. Ruggiero, V. (Ed.). (2000). Crime and Markets: Essays in Anti-Criminology. Oxford: Oxford University Press.

49. King, G., Keohane, R., \& Verba, S. (1994). Designing Social Inquiry: Scientific Inference in Qualitative Research. Princeton (NJ): Princeton University Press.

50. Yin, R. (2003). Applications of case-study research. (2nd ed.). Thousand Oaks: Sage Publications.

51. Bisschop, L. (in press). Out of the woods. Illegal trade in tropical timber and a European trade hub. Global Crime.

52. Mortelmans, D., Decorte, T., \& Zaitch, D. (2009). Observaties. In T. Decorte, \& D. Zaitch (Eds.), Kwalitatieve methoden en technieken in de criminologie (pp. 261-286). Leuven: Acco.

53. Leys, M. (2009). De gevalstudie. In T. Decorte, \& D. Zaitch (Eds.), Kwalitatieve methoden en technieken in de criminologie (pp. 174-194). Leuven: Acco.

54. Yin, R. (2009). Case study research: design and methods. (4th ed.). Thousand Oaks: Sage.

55. Loosveldt, G., Swyngedouw, M., \& Cambre, B. (2007). Measuring meaningful data in social research. Leuven/Voorburg: Acco.

56. VlaamsParlement (6 februari 2009). Interpellatie van de heer Rudi Daems tot de heer Kris Peeters, minister-president van de Vlaamse Regering, Vlaams minister van Institutionele Hervormingen, Bestuurszaken, Buitenlands Beleid, Media, Toerisme, Havens, Landbouw, Zeevisserij en Plattelandsbeleid, over de rol van Vlaamse zeehavens in de export van afvalstromen naar ontwikkelingslanden. Handelingen van de commissievergadering $\mathrm{nr} .133$ van 2008-2009 (pp. 16-26).

57. Holderbeke, J. (2010). Ons vuil in Afrika [Our dirt in Africa]. In R. Vranckx (Ed.), Vranckx (pp. 20:1020:40). Belgium: Canvas.

58. Antwerpse haven draaischijf illegaal afvaltransport [Port of Antwerp hub for illegal waste transports]. (2009, 09/02/2010). Het Laatste Nieuws, p. 11. 
59. Afvallozers glippen te vaak door de mazen van het net [Waste dumpers too often slip through meshes of the net]. (2008, 27/06/2010). De Morgen.

60. Gille, Z. (2006). Detached flows or grounded place-making projects? In G. Spaargaren, A. Mol, \& F. Buttel (Eds.), Governing environmental flows. Global challenges to social theory (pp. 137-156). London/Cambridge (MA): MIT Press.

61. Spaargaren, G., Mol, A., \& Buttel, F. (2006). Governing environmental flows. Global challenges to social theory. London/Cambridge (MA): MIT Press.

62. Gibbs, C., \& Simpson, S. S. (2009). Measuring corporate environmental crime rates: progress and problems. Crime, Law and Social Change, 51(1), 87-107.

63. Croall, H. (2001). Understanding white collar crime. Buckingham - Philadelphia: Open University Press.

64. Sander, K., \& Schilling, S. (2010). Transboundary shipment of waste electrical and electronic equipment / electronic scrap - Optimization of material flows and control: The Federal Environment Agency (Germany) - Ökopol GmbH.

65. Wielenga, K. (2010). Waste without frontiers. Global trends in generation and transboundary movements of hazardous wastes and other wastes. Analysis of the data from national reporting to the secretariat of the Basel convention for the years 2004 - 2006. (pp. 35). Châteleine: Secretariat of the Basel Convention.

66. Fischer, C., Hedal, N., Carlsen, R., Doujak, K., Legg, D., Oliva, J., et al. (2008). Transboundary shipments of waste in the EU. Developments 1995-2005 and possible drivers. (pp. 182). Copenhagen: European Environment Agency - European Topic Centre on Resource and Waste Management.

67. European Commission (2011). Recast of the WEEE Directive. http://ec.europa.eu/environment/waste/weee/index en.htm. Accessed 12 December 2011.

68. VROM-inspectie (2011). Evaluatie en vooruitblik ketenproject elektrische en elektronische apparaten 2010 [Evaluation and preview supply chain project electrical and electronic equipment 2010]. (pp. 51). Den Haag: VROM-Inspectie - Directie Uitvoering.

69. IMPEL-TFS (2006). Is what you see, what you get? : European Union Network for the Implementation and Enforcement of Environmental Law.

70. WCO (2009). Operation Demeter yields tons of illegal shipments of hazardous waste. In W. C. Organization (Ed.). Brussels.

71. Espejo (2010). Assessment of the flow and driving forces of used electrical and electronic equipment from Germany to Nigeria. Brandenburg University of Technology - United Nations University, Institute for Sustainability and Peace, Cottbus.

72. IMPEL-TFS (2005). IMPEL-TSF Threat Assessment Project, the illegal shipments of waste among IMPEL Member States'

73. de Rijck, R. (2011). A flaw in the criminal approach of international waste transport in Europe. Paper presented at the INECE 9th International Conference, British Columbia, Canada, 20-24 June 2011

74. Williams, E., Yu, J. L., Yu, M. T., \& Yang, Y. (2010). Forecasting Global Generation of Obsolete Personal Computers. Environmental Science \& Technology, 44(9), 3232-3237, doi:10.1021/es903350q.

75. CREM (2008). Een analyse van stromen electronica-afval in Nederland [Analysis of e-waste flows in the Netherlands]. Amsterdam: CREM.

76. Environmental Investigation Agency (2011). System Failure. The UK's harmful trade in electronic waste. (pp. 16). London: Environmental Investigation Agency.

77. EPA (2011). Statistics on the Management of Used and End-of-Life Electronics. http://www.epa.gov/osw/conserve/materials/ecycling/manage.htm. Accessed 12 December 2011.

78. Prakash, S., \& Manhart, A. (2010). Socio-economic assessment and feasibility study on sustainable e-waste management in Ghana. (pp. 118). Freiburg: Öko-Instutut e.V.; Inspectorate of the Ministry of Housing, Spatial Planning and the Environment of the Netherlands (VROM-Inspectorate) and the Dutch Association for the Disposal of Metal and Electrical Products (NVMP).

79. Schluep, M., Manhart, A., Osibanjo, O., Rochat, D., Isarin, N., \& Mueller, E. (2011). Where are WEEE in Africa. Findings from the Basel Convention E-waste Africa Programme: Secretariat of the Basel Convention, UNEP, EU, EMPA, Öko-Institut, IMPEL.

80. LNE (2010). Milieuhandhavingsrapport 2009. (pp. 74). Brussel: Vlaamse Overheid - Departement Leefmilieu, Natuur en Energie - Afdeling Milieu-inspectie.

81. Bron voor recyclage valt stil [Source for recycling halts]. (2011, 12 November). De Standaard. 
82. Pensaert, J. Waste controls in Belgian ports ... a matter of cooperation. In International workshop on counteracting illegal waste shipments, Rotterdam, 14-15 November 20112011

83. RILO (2007). Evaluation Report on Project Sky-Hole-Patching. (pp. 32): WCO Regional Intelligence Liaison Office for Asia and the Pacific.

84. Heiss, R., Ruessink, H., Isarin, N., Koparova, M., \& Grabiel, D. (2011). International hazardous waste inspection project at seaports: results and recommendations. Paper presented at the INECE 9th International Conference, British Columbia, Canada, 20-24 June 2011

85. INECE (2010). International hazardous waste inspection project at seaports: Results and recommendations. (pp. 24): INECE Seaport Environmental Security Network.

86. Schmidt, M. (2009). Evaluatie milieubeleidsovereenkomst Afgedankte elektrische en elektronische apparatuur (AEEA). Rapportering over 2008. In OVAM (Ed.).

87. WEEE-forum (2008). WEEE Forum guidance document on compliance with Directive 2002/96/EC on waste electrical and electronic equipment (WEEE): European Association of Electrical and Electronic Waste Take Back Systems

88. Schluep, M., Rochat, D., Wanjira, A. M., Laissaoui, S. E., Wone, S., Kane, C., et al. (2008). Assessing the e-waste situation in Africa. Paper presented at the Electronics Goes Green 2008+,

89. UNEP (2005). E-waste, the hidden side of IT equipment's manufacturing and use. Environmental Alert Bulletin.

90. Bruinsma, G. (1996). De afvalverwerkingsbranche. In G. Bruinsma, \& F. Bovenkerk (Eds.), Inzake opsporing: enquêtecommissie opsporingsmethoden, Deel II onderzoeksgroep Fijnaut: branches. (pp. 261-310). Den Haag: SDU.

91. Sanax, A. (1996). Corporations, organized crime and the disposal of hazardous waste: an examination of the making of a criminological regulatory structure. Criminology, 24(1), 1-27.

92. Babbitt, C. W., Williams, E., \& Kahbat, R. (2011). Institutional Disposition and Management of End-of-Life Electronics. Environmental Science \& Technology, 45(2), 5366-5372, doi:10.1021/Es1028469.

93. Europol (2011). OCTA 2011 - EU Organised Crime Threat Assessment: European Police Office.

94. Levinson, M. (2006). The Box: How the Shipping Container Made the World Smaller and the World Economy Bigger. Princeton, NJ: Princeton University Press.

95. UNODC (2011). Countering the world of smuggling through container control. http://www.unodc.org/unodc/en/frontpage/2011/May/countering-the-world-of-smugglingthrough-container-control.html. Accessed 7 February 2012.

96. Griffiths, H., \& Jenks, M. (2012). Maritime Transport and Destabilizing Commodity Flows (SIPRI Policy Paper). Solna: Stockholm International Peace Research Institute.

97. Kramer, R., Michalowski, R., \& Kauzlarich, D. (2002). The Origins and Development of the Concept and Theory of State-Corporate Crime. Crime and Delinquency, 48(2), 263-282.

98. Amoyaw-Osei, Y., Opoku Agyekum, O., Pwamang, J. A., Mueller, E., Fasko, R., \& Schluep, M. (2011). Ghana eWaste Country Assessment. SBC e-Waste Africa Project. (pp. 111): Green Ad, EPA, Basel Convention, UNEP, EMPA.

99. Odeyingbo, O. A. (2011). Assessment of the flow and driving forces of used electrical and electronic equipment into and within Nigeria. Brandenburgische Technische Universität - United Nations University, Cottbus.

100. Veenstra, A., Wang, C., Fan, W., \& Ru, Y. (2010). An analysis of E-waste flows in China. International Journal of Advanced Manufacturing Technology, 47, 449-459, doi:10.1007/s00170-009-2356-5.

101. Gonzales, A., Schofield, R., \& Hagy, D. (2007). Asian Transnational Organized Crime and Its Impact on the United States. Issues in International Crime (pp. 40). Washington D.C.: National Institute of Justice U.S. Department of Justice Office of Justice Programs.

102. Punch, M. (1996). Dirty business. Exploring corporate misconduct, analysis and cases. London: Sage.

103. Passas, N. (2003). Cross-border crime and the interface between legal and illegal actors. Security Journal, 16(1), 19-38.

104. Van Daele, S., \& Vander Beken, T. (2009). Afvalcriminaliteit en kwetsbaarheden van de afvalsector [Waste crime and the vulnerabilities of the waste sector]. In G. Vande Walle, \& P. Van Calster (Eds.), De criminologische kant van ondernemen [The criminological side of business] (pp. 43-52). Den Haag: Boom Juridische Uitgevers. 
105. Lynch, M., \& Stretesky, P. (2003). The meaning of green: contrasting criminological perspectives. Theoretical Criminology, 7(2), 217-238.

106. White, R. (2008). Crimes against nature: Environmental criminology and ecological justice. Cullompton: Willan Publishing.

107. Passas, N., \& Goodwin, N. (Eds.). (2004). It's legal but it ain't right: harmful social consequences of legal industries. Ann Arbor: University of Michigan Press.

108. Michalowski, R. (2009). Power, crime and criminology in the new imperial age. [Review]. Crime, Law and Social Change, 51(3-4), 303-325, doi:10.1007/s10611-008-9163-z.

109. Basel Convention on the Control and Transboundary Movements of Hazardous Wastes and their Disposal (2010). United Nations. http://untreaty.un.org/cod/avl/pdf/ha/bcctmhwd/bcctmhwd_e.pdf. Accessed June 13th 2011.

110. Miller, T. R., Gregory, J., Duan, H., Kirchain, R., \& Linnel, J. (2012). Characterizing Transboundary Flows of Used Electronics: Summary Report: Massachusetts Institute of Technology, Materials Systems Laboratory, National Center for Electronic Recycling, Solving the E-waste Problem (StEP) and US EPA. 